\title{
Alternative food networks as a counterbalance in the globalized perception of young consumers
}

\author{
Miroslava Navrátilová1, ${ }^{1}$, Josef Abrhám ${ }^{1}$, Markéta Beranová ${ }^{1}$ and David Brož ${ }^{1}$ \\ ${ }^{1}$ Czech University of Life Sciences in Prague, Kamýcká 129, Prague, 165 21, Czech Republic
}

\begin{abstract}
The phenomenon of alternative food networks is becoming increasingly important, especially in the context of changes in consumer behavior and business sustainability. The distribution channels of some products place a disproportionate burden on the environment. In this context, the issue of local food production and the use of local distribution channels are becoming increasingly important as counterbalances of international trade processes in the context of globalization. New food-specific forms include alternative food networks. Sustainability is a topical issue, especially among young consumers, who are sensitive to environmental issues and like all new things. This consumer target group will shape the future of the current globalized world. The aim of the paper is to evaluate the general level of awareness among young people aged 20 - 34 in the Czech Republic about alternative forms of purchasing food and to identify knowledge of different forms of this sale. Primary research data was used to evaluate preferences in 2019. The total number of participants was 519 respondents. The results show that more than half of the respondents have ever encountered the concept of an alternative food network. Most often, respondents said they had personal experience of selling on farm markets and selling organic food.
\end{abstract}

\section{Introduction}

In the last decades, structural changes in the agri-food system took place due to globalization, industrialization and concentration [1]. Along with globalization, a whole range of problems appeared in connection with the state of the environment and the future of the planet. Sustainable consumption and production are thus at the forefront of the expert and non-expert public and producers [2]. In developed parts of the world, consumer demand is met through global food systems. These conventional food systems are characterized by anonymity, homogenization and standardization of their supply, and they are also associated with overconsumption and mass production [3].

From the point of view of globalization, the complex and long distribution channels of products on the way to the consumer and his separation from the place of production of food are perceived negatively. One of the trends in contributing to sustainable development appears implementation of processing and distributing of production via local context. This

*Corresponding author: navratilovam@pef.czu.cz 
contributes to strengthening the social links in the place and perception of the quality of production [4]. Production in European Union in agri-food system is closely linked to regional development, the environment and public health [5].

Alternative food networks (hereinafter AFN's) are different from conventional food systems [6] and their most important characteristics of these distribution channels are spatial proximity between farmers and consumers and clear information about the producer, the place of production and the production system [7]. AFN's could be counterbalance to globalization processes in the area of food sales [8] their definition is a relatively complex matter, as they can take various forms in terms of specific goals and forms of organization [9]. Alternative food networks are a specific form of production, distribution and consumption in Europe, North America and Australia [7].

Ethical principles of consumption are becoming more important in developed countries in today's globalized world [10]. Promoting ecological consumer behavior is becoming one of the key factors of environmental sustainability, and consumer sensitivity to social and environmental issues is also increasing [11]. Consumers have opportunity to express their views and attitudes when purchasing and to find an alternative way of expressing their personal standards [12]. Today's young people in developed countries are demanding and independent consumers because they live their lives in wellbeing [13].

The aim of the paper is to evaluate the general level of awareness among young people aged 20 - 34 in the Czech Republic about alternative forms of purchasing food and to identify their knowledge of different forms of this sale.

The chapter Introduction introduces theoretical framework of the issue. The chapter Methods and Materials describes methods used in the paper and provides a description of the sample of primary research through socio-demographic characteristics. In the chapter Results and Discussion are presented the results, which are discussed. The most important findings are summarized in the Conclusion chapter.

\section{Methods and Materials}

The theoretical framework of this article has been elaborated through the method of document research using scientific articles.

To obtain primary data, quantitative research was carried out by questionnaire survey. Of the total number of respondents $(n=519)$, were $39.9 \%$ (207) men and $60.1 \%$ (312) were women. The respondents were young people from the Czech Republic, aged 20 - 34 years. Age categorization of respondents was determined based on Czech Statistical Office criteria. Individual age categories of respondents were represented as follows. The category 20-24 years included $58.4 \%$ (303), the category $25-29$ years $27.3 \%$ (142) and young people aged $30-34$ years contributed $14.3 \%$ (74 persons) to the total number of respondents. The research was carried out in 2019 with the use of electronic and personal questionnaire.

The paper will be processed using the methods and tools of descriptive and inferential statistics. A contingency table is used to test the mutual degree of association of (usually) a pair of variables that can only take a small final number of values. In its simplest form, which compares only binary values, this table is also called a four-field table (or $2 \times 2$ ). The tested criterion is the sum of normalized differences of the marginal frequencies and their translated values, which in the case of independency has an asymptotic distribution of $\chi^{2}$. The calculated value is then compared to the critical value $\chi^{2}(\alpha)$ with (r-1)(s-1) degrees of freedom, where $\alpha=$ the required probability level of the test, $r=$ number of rows of the table, $s=$ number of columns of the table. The potential correlation (or absence thereof) was tested by the way of contingency tables, with an $\chi^{2}$ test at the 0.05 level $[14,15]$. Various coefficients may be used to measure the strength of correlation. Cramer's $V$ was obtained, and strength of the dependence was evaluated by Corbet [16]. 
The null hypotheses that were determined and subsequently tested are summarized in the following table (Table 1.).

Table 1. Summary of selected hypotheses.

\begin{tabular}{|c|c|}
\hline Nr. of Hypothesis & Hypothesis \\
\hline $\mathrm{H}_{1}$ & $\begin{array}{r}\text { The respondent's opinion on the importance of the state of the } \\
\text { environment does not depend on sex. }\end{array}$ \\
\hline $\mathrm{H}_{2}$ & $\begin{array}{r}\text { The respondent's opinion on the importance of the state of the } \\
\text { environment does not depend on the respondent's age category. }\end{array}$ \\
\hline $\mathrm{HO}_{3}$ & $\begin{array}{r}\text { The level of awareness of the concept of alternative food } \\
\text { networks does not depend on gender. }\end{array}$ \\
\hline $\mathrm{H}_{4}$ & $\begin{array}{r}\text { The level of awareness of the concept of alternative food } \\
\text { networks does not depend on the respondent's age category. }\end{array}$ \\
\hline
\end{tabular}

Source: own research, 2019

\section{Results and Discussion}

The results show that more than $90.0 \%(91.9 \%, 477)$ of the total number of respondents $(\mathrm{n}=$ $519)$ consider the state of the environment to be important. More than half of the respondents $(52.8 \%, 274)$ identified the answer "definitely yes" and $39.1 \%$ (203 persons) chose the answer "rather yes". The current young generation is more interested in the environment than previous generations [17].

Less than $7.0 \%$ of respondents declared a negative attitude $(6.7 \%, 35$ persons in total, of which 32 were "definitely no" and 3 were "rather no"). 1.3\% (7) of the respondents declared a lack of interest ("not interested" answer). These three categories were merged for statistical testing of null hypotheses.

Table 2. Contingency table for tested hypothesis $\mathrm{H}_{1}$.

\begin{tabular}{|c|c|c|c|c|}
\hline $\begin{array}{c}\text { Gender of } \\
\text { respondent }\end{array}$ & $\begin{array}{c}\text { Definitely } \\
\text { yes }\end{array}$ & $\begin{array}{c}\text { Rather } \\
\text { yes }\end{array}$ & $\begin{array}{c}\text { Definitely No, rather no, not } \\
\text { interested }\end{array}$ & Total \\
\hline Male & 91 & 88 & 28 & 207 \\
\hline Female & 183 & 115 & 14 & 312 \\
\hline Total & 274 & 203 & 42 & 519 \\
\hline
\end{tabular}

Source: own research, 2019

The value of $\chi^{2}$ (18.67) is higher than the critical value of $\chi^{2}$ (5.99) by 2 degrees of freedom at the 0.05 level. The null hypothesis can be rejected. The respondent's opinion on the importance of the state of the environment depends on the respondent's sex. However, the dependence measured by Cramer's $\mathrm{V}$ is weak $(\mathrm{V}=0.19)$. The analysis of the adjusted residues method shows that the statistically significant difference from the theoretical frequencies at the significance level of 0.001 is manifested mainly in the positive attitudes of women in terms of environmental interest.

The value of $\chi^{2}$ (6.18) is lower than the critical value of $\chi^{2}$ (9.49) by 4 degrees of freedom at 0.05 . The null hypothesis cannot be rejected. The respondent's opinion on the importance of the state of the environment therefore does not depend on the age category. Environmental status is considered most important by young people aged 20-24, with $93.7 \%$ of the positive answers (' Definitely yes and 'rather yes') within the age category. 
Table 3. Contingency table for the tested hypothesis $\mathrm{H}_{2}$.

\begin{tabular}{|c|c|c|c|c|}
\hline $\begin{array}{c}\text { Age category of } \\
\text { respondent }\end{array}$ & $\begin{array}{c}\text { Definitely } \\
\text { yes }\end{array}$ & $\begin{array}{c}\text { Rather } \\
\text { yes }\end{array}$ & $\begin{array}{c}\text { Definitely No, rather no, not } \\
\text { interested }\end{array}$ & Total \\
\hline $20-24$ years & 167 & 117 & 19 & 303 \\
\hline $25-29$ years & 68 & 61 & 13 & 142 \\
\hline $30-34$ years & 39 & 25 & 10 & 74 \\
\hline Total & 274 & 203 & 42 & 519 \\
\hline
\end{tabular}

Source: own research, 2019

Furthermore, the level of awareness and knowledge of the concept of alternative food networks in general was examined. More than half of the respondents $(57.4 \%, 298)$ stated that they had already encountered the term in some form. However, only less than a third of respondents $(29.9 \%, 89$ persons) were sure about that they knew the exact content of the concept of alternative food networks. So most respondents agreed that they had heard about the term, but did not know its exact content. Young people emphasize the health, quality and freshness of the products they buy [18] and value of authenticity [13].

Table 4. Contingency table for tested hypothesis $\mathrm{H}_{3}$.

\begin{tabular}{|c|c|c|c|c|}
\hline $\begin{array}{c}\text { Gender of } \\
\text { respondent }\end{array}$ & Definitely yes & $\begin{array}{c}\text { Rather } \\
\text { yes }\end{array}$ & $\begin{array}{c}\text { Definitely No, } \\
\text { rather no, not } \\
\text { interested }\end{array}$ & Total \\
\hline Male & 17 & 86 & 104 & 207 \\
\hline Female & 72 & 123 & 117 & 312 \\
\hline Total & 89 & 209 & 221 & 519 \\
\hline
\end{tabular}

Source: own research, 2019

The value of $\chi^{2}$ (20.92) is higher than the critical value of $\chi^{2}(5.99)$ by 2 degrees of freedom at the 0.05 level. The null hypothesis can be rejected. The level of knowledge and awareness of the concept of alternative food networks depends on the gender of the respondent. The dependence measured by Cramer's V is weak $(\mathrm{V}=0.20)$. Adjusted residue analysis shows that the statistically significant difference from theoretical frequencies (significance level 0.001) is a higher level of knowledge and awareness of the concept of AFN's in women.

Table 5. Contingency table for tested hypothesis $\mathrm{H}_{4}$.

\begin{tabular}{|c|c|c|c|c|}
\hline $\begin{array}{c}\text { Age category of } \\
\text { respondent }\end{array}$ & Definitely yes & $\begin{array}{c}\text { Rather } \\
\text { yes }\end{array}$ & $\begin{array}{c}\text { Definitely No, } \\
\text { rather no, not } \\
\text { interested }\end{array}$ & Total \\
\hline 20-24 years & 36 & 119 & 148 & 303 \\
\hline $25-29$ years & 34 & 62 & 46 & 142 \\
\hline $30-34$ years & 19 & 28 & 27 & 74 \\
\hline Total & 274 & 203 & 42 & 519 \\
\hline
\end{tabular}

Source: own research, 2019

The value of $\chi^{2}(19.35)$ is higher than the critical value of $\chi^{2}(9.49)$ by 4 degrees of freedom at the 0.05 level. The null hypothesis can be rejected. The level of knowledge and awareness of the concept of alternative food networks depends on the gender of the 
respondent. The dependence measured by Cramer's $\mathrm{V}$ is week $(\mathrm{V}=0.14)$. Based on the analysis of adjusted residues, it was found that young people aged 20-24 show a statistically significantly lower knowledge of the term AFN's than other age categories.

Furthermore, the personal experiences of young people with specific forms of food sales within alternative food networks were investigated. The summary results are summarized in the following table (Table 6.).

Table 6. Respondents' personal experience with any of specific forms of food sale.

\begin{tabular}{|c|c|c|}
\hline Individual specific forms of sale & Absolutely & Relatively \\
\hline Direct sale at farmers markets & 465 & 89.6 \\
\hline Sales at farmers shops & 313 & 60.3 \\
\hline Sales at "farmyards" & 266 & 51.3 \\
\hline Sale with the use of pre-paid so-called "boxes" & 120 & 23.1 \\
\hline Organic food sale & 396 & 76.3 \\
\hline Regional specialities sale & 278 & 53.6 \\
\hline Fairtrade product sale & 234 & 62.4 \\
\hline Community supported agriculture & 34 & 6.6 \\
\hline Community gardens & 62 & 6.2 \\
\hline
\end{tabular}

Source: own research, 2019

The results obtained show that most respondents have already encountered some of the specific forms of AFN's sales. Less than 90.0\% $(89.6 \%, 465)$ of the total number of respondents $(n=519)$ reported having personal experience of direct sales on farmers' markets and more than three quarters $(76.3 \%, 396)$ of respondents labeled 'organic food sale' .

In the Czech Republic, the phenomenon of farmers' markets shows an upward trend [19].

Approximately $60.0 \%(60.3 \%, 313)$ encountered sales at farmers shops. More than half of the respondents stated that they personally met regional specialties sale $(53.6 \%, 278)$ and sales at farmyards $(51.3 \%, 266)$. Sales via prepaid boxes were $23.1 \%(120)$.

These findings confirm the trend of increasing demand for organic food and domestic products of local character [20]. In both global and local markets, there are more and more products that appeal to consumers through their moral value [21].

The sale of Fairtrade products has a specific position in alternative food networks. This production is grown in the countries of the global South and is transported over long distances to the countries of the rich global North. Even in this case, however, this is an attempt to facilitate the most direct distribution channel between the producer and the consumer. For this reason, in the broader context, this form of sale is also included in AFN's [22]. The idea of Fair Trade is a relatively well-known phenomenon among young people in the Czech Republic.

Only a small number of young people experienced personal experiences with community supported agriculture $(6.6 \%, 34)$ and community gardens $(6.2 \%, 62)$. In the countries of the global North, rapid growth in interest in urban agriculture [23] can be observed, particularly in connection with the pursuit of quality food. In the Czech Republic, the main cause of these activities is the efforts to strengthen local communities and thus carry mainly the social dimension [24]. 


\section{Conclusion}

The aim of the paper is to evaluate the general level of awareness among young people aged 20 - 34 in the Czech Republic about alternative forms of purchasing food and to identify their knowledge of different forms of this sale.

There were statistically significant differences between the responses of men and women in the perception of environmental issues and in terms of awareness of alternative networks. When women show a higher level of knowledge in both cases

The results show that approximately $90.0 \%$ of young people from total number of young people $(n=519)$ thought that environment is important. More than half of the respondents expressed general awareness of the concept of alternative food networks, but most of them are not sure about the exact content of the term. In terms of individual specific forms of food purchase, respondents most often encountered direct sales of food on farmers' markets, organic food and Fairtrade production.

The limits of the research can be seen in the fact that the research took place only in the territory of one state - the Czech Republic. Other suitable directions of further research include the implementation of a similar questionnaire survey in other Member States of the European Union.

This paper is a partial result of the research project No. 2019B0010 - Czech Social System Fraud Rate Estimation and System Optimization Proposals, supported by the Internal Grant Agency (IGA) of Faculty of Economics and Management, CULS Prague.

\section{References}

1. M. K. Hendrickson, Resilience in a concentrated and consolidated food system. Journal of Environmental Studies and Sciences 5, 418-431 (2015)

2. D. Goodman, E. M. DuPuis, M. K. Goodman, Alternative food networks: Knowledge, practice and politics (London, Routledge, 2012)

3. G. O'Kane, G., Contemporary relational food cultures emerging from local food networks. Appetite 105, 218-231 (2016)

4. L. Cembalo, G. Migliore, F. Caracciolo, G. Schifani, Organic consumption and consumer participation in food community networks. New Medit 11, 46-48 (2012)

5. A. Wezel, J. Goette, E. Lagneaux, G. Passuello, E. Reisman, C. Rodier, G. Turpin, Agroecology in Europe: Research, education, collective action networks, and alternative food systems. Sustainability 10, 1-18 (2018)

6. F. Barbera, J. Danges, Building alternatives from the bottom-up: The case of alternative food networks. Agriculture and Agricultural Science Procedia 8, 324-331 (2016)

7. L. Jarosz, The city in the country: Growing alternative food networks in metropolitan areas. Journal of Rural Studies 24, 231-244 (2008)

8. J. Spilková, Alternativní potravinové sitě: česká cesta (Praha, Karolinum, 2016)

9. E. Dansero, M. Puttilli, Multiple territorialities of alternative food networks: six cases from Piedmont, Italy. Local Environment 19, 626-643 (2014)

10. A. Coppola, F. Verneau, F. Caracciolo, T. Panico, Personal values and pro-social behaviour: The role of socio-economic context in fair trade consumption. British Food Journal 119, 1969-1982 (2017)

11. E. Jerzyk, Design and communication of ecological content on sustainable packaging in young consumers' opinions. Journal of Food Products Marketing 22, 707-716 (2016) 
12. M-Y. Lee, V. Jackson, K. A. Miller-Spillman, E. Ferrell, Female consumers' intention to be involved in fair-trade product consumption in the U.S: The role of previous experience, product features, and perceived benefits. Journal of Retailing and Consumer Services 23, 91-98 (2015)

13. J. Van den Bergh, M. Behrer, Jak cool značky zůstávají hot: marketing zaměřený na mladou generaci Y (Brno, BizBooks, 2012)

14. R. Hindls, S. Hronová, J. Seger, J. Fischer, Statistika pro ekonomy (Praha, Professional publishing, 2007)

15. J. Hendl, Přehled statistických metod: analýza a metaanalýza dat (Praha, Portál, 2009)

16. 1M. Corbett, Research Methods in Political Science: An Introduction Using MicroCase (Boston, Wadsworth/Thomson Learning, 2001)

17. R. Yadav, Altruistic or egoistic: Which value promotes organic food consumption among young consumers? A study in the context of a developing nation. Journal of Retailing and Consumer Services 33, 92-97 (2016)

18. DH. Kim, SCh. Jang, Motivational drivers for status consumption: A study of Generation Y consumers. International Journal of Hospitality Management 38, 39-47 (2014)

19. L. Zagata, 'We Want Farmers' Markets!' Case Study of Emerging Civic Food Networks in the Czech Republic. International Journal of Sociology of Agriculture and Food 19, 347-364 (2012)

20. A. Vrsaljko, N. Čukelj, Natural and Cultural Heritage as a Paradigm for Agrotourism Development in Krapina-Zagorje County. Agriculturae Conspectus Scientificus 80, 229238 (2015)

21. S. Tang, C. Arciniegas, F. Yu, J. Han, S. Chen, J. Shi, Taste moral, taste good: The effects of Fairtrade logo and second language on product taste evaluation. Food Quality and Preference 50, 152-156 (2016)

22. V. Bezençon, Producers and the Fair Trade Distribution Systems: What are the Benefits and Problems? Sustainable Development 19, 60-70 (2011)

23. A. Viljoen, J.S.C. Wiskerke, Sustainable food planning: evolving theory and practice (Wageningen, Wageningen Academic Publishers, 2012)

24. J. Spilková, Producing space, cultivating community: The story of Prague's new community gardens. Agriculture and Human Values 34, 887-897 (2017) 